\title{
Contributing to the common good? Media Coverage of the International Largescale Assessment of Adult Skills (PIAAC) in Four National Contexts
}

\author{
Mary Hamilton, Lancaster University UK.
}

\begin{abstract}
This paper focuses on the rapidly expanding field of largescale international assessment surveys and their impact on the field of adult education and learning. I take the case of OECD's survey assessing adult skills (PIAAC) and situate it within the wider context of the datification of educational policy and practice.
\end{abstract}

The claims made for the policy effects of surveys like PIAAC are far-reaching and include the promotion of economic growth and more inclusive and equitable societies. I examine how these claims are translated into national contexts by examining documentary data collected from the OECDs publicity materials and media coverage of the second round PIAAC survey findings in 2016 in four of the nine countries that took part: Singapore, Greece, New Zealand and Slovenia. Using a socio-material approach, I discuss how these discourses were managed by the OECD and national actors and show how the survey findings are framed and interpreted through existing public debates. The paper concludes that international assessments do not serve the goals of growth and equity in any straightforward way, since many interests and contextual factors may intervene to create a mismatch between the testers' intentions, media discourse and policy outcomes.

Key words: adult skills; international assessment studies; media analysis; policy discourse 


\section{Introduction}

In 2014, the International Journal of Lifelong Education carried an editorial which identified the need for contributions to scholarship about the rapidly expanding field of international assessment surveys and their impact on the field of adult education and lifelong learning (Milana et al 2014). The present paper responds to that editorial suggestion and contributes to the already burgeoning body of research into the OECD's adult skills survey, the Programme for the International Assessment of Adult Competencies (PIAAC). It focuses specifically on how the survey findings are incorporated into public discourse through national media.

International Largescale surveys of achievement (ILSAs), especially measures of literacy and numeracy, have developed over recent years into a significant global endeavour (see Addey et al 2017). For international agencies like the OECD and UNESCO who have no statutory say over the educational policies of individual nation states, such surveys are an important tool of "soft power" to influence the global community toward future-oriented reform (Henry et al 2001).

Many of these surveys, including the Programme for International Student Assessment (PISA), the best known of them, focus on schoolchildren's attainment but PIAAC is the OECDs latest attempt to measure the more diffuse field of adult skills. PIAAC replaces the earlier International Adult Literacy Survey (IALS) and the survey of Adult LifeLong Learning (ALL) and extends the reach of the assessment to a wider range of countries than ever before (Kirsch and Lennon, 2017). 24 countries participated in the first round of PIAAC in 2013, and a further 9 countries were added in a second wave (hereafter PIAAC\#2) . 
Grek (2010) observes that PIAAC plays a special role within the developing field of international assessment. It is a landmark development in the lifelong monitoring and international comparison of education because, through its design and inclusion of common test items, it links school-based assessments like PISA with earlier surveys of adult skills The International Adult Literacy Survey (IALS) and the Adult Literacy and Lifeskills Survey (ALL). Adult skills are more challenging to define than school-based subject areas. They cross the policy domains of education, employment and citizenship, each of which have their own interest groups, competing discourses and struggles for visibility in the public sphere. PIAAC thus draws together a new constellation of social actors, public audiences and discourses. It offers flexible possibilities (what Carvalho, 2012 calls 'plasticity') for fusing diverse interests into a common project, appealing to new publics who can, in turn, mobilise governments. PIAAC is thus a key move in realising an ambitious programme of datification of knowledge for policy.

The PIAAC is a household survey which tests three dimensions of achievement: Literacy, Numeracy and Problem-solving in Technology-rich Environments (PSTRE). The test includes selected Literacy and Numeracy items from the previous IALS and ALL surveys, and from PISA, while PSTRE is an entirely new dimension. Those taking the test also complete a background questionnaire which generates rich data about participants' demographic profiles, social attitudes, educational and employment experiences.

The explicit aim of PIAAC is to intervene in national policy in order to improve equity, prosperity and engagement with a global, future-oriented vision (see Hannushek and Woessmann, 2015; OECD, 2013). In this paper I consider how far PIAAC might function as an engine for change in this way. While some research looks at this issue by 
examining the validity of test construction and of direct policy impact, this paper is concerned with the processes whereby the survey findings engage national actors through the public media, seeing this as one significant factor that intervenes between test design and policy response.

The paper builds on a comparative study of media coverage of the first round of PIAAC (Yasukawa et al. 2016). It takes a socio-material approach to the policy process (Fenwick, Edwards, and Sawchuk 2011) that focuses on how the elements of the international assessments - the test items themselves, the numbers and data displays, the scientific, media and policy reports produced in relation to them come into being through the decision-making and communication processes of organizations and social networks and how they take on agency as material artefacts within national contexts.

Gorur (2011) identifies a set of steps that take place in the construction and delivery of any comparative test of skills. These translate divergent realities and knowledges and "matters of concern" into the "matters of fact" represented by test scores. At each stage, decisions are made which set boundaries around the data that will be generated and solidify knowledge. Test-makers have to

- Choose which items will represent the domains of knowledge

- Decide when and how to translate these across cultures and languages

- Decide on a sample to represent the population

- Agree on methods of data collection and how to ensure these are consistently carried out.

- Select which statistical techniques to apply to the data.

None of these are common-sense decisions. They are infused with values and assumptions that are not necessarily shared by all interested parties. In her account of 
the construction of the PISA test, for example, Gorur describes how the vast array of possibilities of what and how to assess at each stage of decision-making give rise to a process that was "rife with debate and contestation" (2011:82; see also Guadaloupe, 2015 on similar controversies in a UNESCO initiative). As the project moves forward, however, the debates around these decisions are forgotten or become invisible and they appear to have been merely technical procedures. In this way, the nature of skills and what counts as achievement of them is shaped or "fabricated" by the test-makers rather than "discovered".

In (Hamilton, forthcoming) I describe a number of unstated but powerful assumptions that underlie the OECD's approach to testing adult skills which have become naturalised as common sense. The tests promote a model of skills that is based on an imagined future envisioned by techno-experts (Ozga et al, 2011) and composed of competing nation states. Skills are defined as individual performances of information processing and personality based in psychometric theory, removing them from the relational, situated practices of which they are a part. Comparison proceeds along a single dimension for each measured skill, implying a universal, decontextualized curriculum (Sellar and Lingard, 2015). The model emphasises economic and workrelated aspects of skills while other dimensions of social life are less visible. In line with the tenets of evidence-based policy (Pawson, 2002) valid evidence is assumed to be large-scale and aggregated, while small-scale, historical and contextualised comparisons based on local experience are dismissed as unreliable and backward-facing.

One important effect of this approach is that the technicisation of basic skills renders lay people incompetent to assess their own (or others') skills and specialised expertise is needed to interpret the largescale survey data. Journalists and researchers are increasingly being offered workshops to develop such specialist skills (see O’Keefe, 
2015; Knight, 2015). The use of externally defined yardsticks and specialist interpreters of performance in themselves may thus pose a challenge to goals of inclusiveness and relevance as they remove decision-making about assessment from educators and learners and hand it over to distant actors.

\section{How PIAAC findings travel: diffusion of a policy initiative}

\section{Creating publics - managing release of the findings to key actors}

As a project of largescale comparative testing moves forward, the fabrication of facts continues. The scores are interpreted and released into the arenas of public discourse, circulating in national conversations through the media and targeted communications with policy-makers and advocates.

In addition to those identified by Gorur (2011) there are several further stages involved in embedding international findings within national contexts: securing national participation in the surveys, managing the release of the findings in national and international policy domains and achieving media publicity for them. This paper focuses on the latter in the belief that the current mediatisation of education policy makes the role of the media a crucial domain for investigation (Rawolle and Lingard, 2014; Stack (2016); Kelly, 2011) . A small literature is beginning to explore the role of the media in relation to adult education policy. Rubenson and Walker (2014) found that media coverage of the IALS had significantly affected policy discourse in Canada while, in contrast, Cort and Larson (2015) found little attention was paid to PIAAC in Denmark. The comparative study carried out by Yasukawa et al (2016) found responses varied across Japan, France and the UK. In a more general review of how ILSAs are presented in the media and impact on policy, Fishman et al (2017) conclude that survey 
findings tend to be recruited as a "rhetorical ally" used to legitimate existing policies or plans for reform, rather than promoting a change of direction.

In other papers, I examine the complementary processes of building a common discourse for PIAAC (Hamilton, 2017; Hamilton, forthcoming) and the reception of ILSAs as policy interventions in national contexts. In these papers I review evidence showing that the ways in which policy reforms travel (or not) across national boundaries, how they are adapted and reframed is not a passive process (see SteinerKhamsi, 2014). In the case of ILSAs, policy actors and advocates in individual countries actively engage in the creation of the survey findings and their interpretation.

Briefly, individual countries are not compelled to take part in PIAAC but choose to participate for a variety of reasons (see Addey and Sellar, 2017). The testing agencies themselves (in this case the OECD) manage the release of the findings, controlling timing and identifying particular issues as relevant and significant for policy reform. Such management takes the form of embargoes, press releases, simplified and interactive versions of the findings online and in print, webinars and launch events, blogs and tweets. In the case of PIAAC\#2, the OECD organized launch events in 5 of the 9 countries to which high profile OECD officers and national ministries contributed and journalists were invited. These were linked to press releases and to individual country notes (a compressed summary of key issues and implications) that could be used in the subsequent media coverage.

It is important when looking at the invariably reduced versions of the PIAAC findings that make their way into the public media to be aware that a great deal of information about the survey methodology, aims and data can be found on-line. The OECD makes a huge effort toward transparency and encourages policy makers and researchers to work with the data to do their own analysis, explorations and 
interpretations on particular topics. This is leading to a whole industry of secondary analysis which aims to exploit the potential of the data by exploring in depth particular variables or themes and the relationships between them (see for example Coben et al, 2016 which uses data from the background questionnaire to analyse numeracy practices in everyday life). The OECD also monitors the impact of the findings in the media and worries about how to better engage and convince people of the messages carried by the findings (See Roseveare, 2014:3)

\section{Documenting the Media coverage of PIAAC \#2}

The data for this study come from primary research on internet documents and media reports of the survey findings during the week following their release (June $28^{\text {th }}-$ July $5^{\text {th }}$ 2016). A two-stage design was used to collect and interpret the data.

To interpret the media coverage it was important to have basic background information about each country and its media industry so in the first stage, collaborators with first-hand knowledge of the participating countries were asked to collect newspaper and online articles that refer to the PIAAC\#2 findings in their country and to write a short report about them which would answer the following questions, derived from the outcomes of our earlier research (Yasukawa et al 2016):

(1) What results are presented in the media (rankings, country scores, within country group differences such as age or gender)?

(2) What policy issues are drawn from the results?

(3) Do the reports simply summarise or extract from the OECD country notes, or is there an attempt to provide richer interpretations?

(4) What reference countries are mentioned (positive and negative), and is the general tone of the results positive or negative? 
(5) Is the survey methodology mentioned or critiqued in the reports?

Informants were all engaged in the field of adult learning as academic researchers or practitioners ${ }^{\text {ii. }}$. They were asked to identify items in national newspapers, popular broadcast and online sources that cover the political spectrum.

Keiko Yasukawa and I also carried out newspaper keyword searches using the Factiva and Nexus newspaper databases to systematically pick up any items that our informants may have missed. While there was much overlap, both the databases and the informants uniquely listed items not found in the other source. Database results have to be "cleaned" as they contain repeated items, official government, OECD and EU documents and business collating services that offer secondary sources and circulate press releases. News items published in national languages are often missed as the scope of the survey moves beyond English-speaking and major European countries to those whose media may not have much international visibility.

In the second stage, my role was to look across the reports produced by the incountry informants and the complete set of media items to add a further layer of interpretation and analysis. In particular, I summarised the issues in the individual country notes produced by the OECD which had accompanied the release of the findings, and compared these with the media coverage in each country.

The coverage was very uneven across countries and generally less extensive than we had expected, based on previous international surveys. In the following sections I discuss the detailed media responses of 4 countries chosen for their relative places in the league table and for which a reasonable amount of documentation could be assembled.

Appendix 1 lists the items collected from the four countries chosen for in-depth analysis, including details of their source and main headline. These are numbered for 
reference in the main text. Appendix 2 details the issues highlighted by the OECD country notes for each of the 4 case study countries.

\section{Singapore and Greece}

I chose Singapore because it was prominently featured as an example of good practice by Schleicher (2016) in his publicity about the survey. I chose Greece as a contrasting example of a country that scored low in the rankings, and is a good candidate for "PIAAC-shock"- that is, a response that has been observed in countries scoring unexpectedly poorly in international comparisons and which disrupts existing public discourse and puts pressure on policy-makers to respond with new reforms. (see Hopfenbeck \& Görgen, 2017).

Neither Singapore nor Greece had participated in an adult skills survey before. Both countries had websites dedicated to PIACC with downloadable brochures and videos, suggesting that the exercise was taken reasonably seriously by the co-ordinating agencies in each. Both countries generated a good deal of media coverage. Both were ranked below the OECD average in literacy and numeracy, but scored very differently in problem-solving (PSTRE) with Greece near the bottom and Singapore well above the average. The context and current situation of the two countries is very different as is the way the media treated the findings from the PIAAC and the ways in which the OECD and others interpreted their performance.

Singapore is a rich city state of 5.5 million multilingual people. It has high employment. With no natural resources of its own, the economy depends on a large service sector and trading links with other countries in the Southeast Asia region. The state government keeps tight control over many aspects of the economy including migration. It owns the media outlets and has invested heavily in recent years in 
education, including continuing vocational education. It has serious policies in place for developing education, human resources and technology (see Luke et al 2005; Tan, 2017). The economy has faltered in recent years but is stabilising again. It is possible to see Singapore, therefore as mirroring the aspirations of the OECD for PIAAC and for developing lifelong learning.

In the PIAAC survey, younger Singaporean adults achieved much higher scores than their elders. This disparity could be explained by the lack of educational opportunities experienced in the past by older adults, and by the fact that around $85 \%$ of older adults do not have English (the sole language of the test) as their mother tongue.

Greece is a member of the European Union and has been suffering from extreme economic difficulties in recent years. The official language is Greek which is spoken by almost everyone in the population, estimated at around 11.2 million in 2007 according to the European Journalism Centre (EJC). It currently has an unemployment rate of $25 \%$ which rises to $45 \%$ among $16-25$ year olds. Political debate is fierce in the country with a controversial change of government in recent years toward the left and the live possibility of an exit from the EU due to inability to settle national debts. These debates are evident in the coverage of a competitive, privately owned media with a variety of political affiliations. The weakness of the economy has meant that Greece has been subject to reforms imposed by the EU, including curtailment of public funding and state control, which are unresolved and have been highly contested. Within these constraints, accredited continuing and vocational education has developed in line with EU policy, largely delivered by private training organizations. This is a weakened and demoralised country that is unlikely to take further bad news well.

In the PIAAC survey, Greece scored among the bottom countries, next to its close neighbour Turkey, and to Chile and Indonesia. It was significantly below the 
OECD average in all three dimensions. Despite the fact that access to education and participation rates have greatly improved for younger people, their performance was not much better than the older age groups. Two unusual results were that women scored more highly than men, and there was no relationship between unemployment and skill achievement.

So, what did the OECD and the media make of these results?

Firstly, the OECD country notes for both countries highlight the age differences in achievements, making important assumptions. For Singapore it is assumed that the higher level of achievement of the youngest groups is an endorsement of the educational reforms of recent years although the language issue is also mentioned as a likely impediment for the older adults "The high prevalence of adults whose native language is different from that of the assessment (English) contributed significantly to belowaverage proficiency" (See Appendix 2). The success of Singapore's educational reforms is foregrounded in Andreas Schleicher's commentaries (a newspaper article, blog, webinar and a video addressed to an international audience) and although Singapore is not top of the league table of nations, it is held up as a positive role model ("glorified" -see Steiner Khamsi 2003) for other developing countries. The aspects singled out in the OECD country notes are also picked up by the media which in most respects keep close to the OECD's text and also draw on an extended, positive government press release (Singapore Made Significant Progress in Enhancing Literacy, Numeracy, Problem-Solving Skills of our People, June $28^{\text {th }}$ )

For Singapore, 16 news items were examined which include 4 Chinese language sources. The tone is factual (neither glorifying nor scandalising) and very little reference is made to the political or policy context, except to say that the government's existing substantial educational reform strategies, including the lifelong learning SkillsFuture 
programme (Tan, 2017) seem to be paying off and are appropriately addressing the needs of the adult population. The Workforce Development Minister is quoted in several articles, alongside the OECD's Andreas Schleicher, with a notable emphasis on Singaporeans as workers. The age disparity in achievement and the associated language issue, in particular, is widely taken up in media reports including Asia news, The Straits Times and the Chinese language newspaper, Lianhe Zaobao. The media referred to a wide range of other countries from Europe, Asia and North America. Three comment pieces (SING9,10 \&11) pick out some employment related issues highlighted by the OECD but ignored by the other media but these do not critique either the survey methodology nor the national policy.

The coverage we examined from Greece consisted of 8 news items. There were several items in business related news sources (see GR3), as well as general and educational publications. As in Singapore, the media reports stayed close to the OECDs own summaries in reporting factual aspects of the survey findings, but their explanations of what were clearly regarded as dismal findings differed from the OECDs measured tone, strongly reflecting ongoing political controversies and tensions and the desperate circumstances of contemporary Greek society, especially the plight of younger people. While some articles were highly critical of government policy and the education system in particular (see GR5), they also focussed on the massive exodus of Greek citizens to other countries. 400,000 have left since 2008 , mostly professional skilled adults and many younger people. Given that the overall population of Greece is 11.2 million this is seen as a number significant enough to skew the results of the survey. A comment piece in the daily newspaper Kathimerini (GR 8) uses PIAAC and Bank of Greece survey on Greek emigration to critique the education system and the SYRIZA government. Although it was outside the period of coverage studied for this 
paper, a statement later in July from a business organization, The Hellenic Federation of Enterprises (SEV) made this point and prompted discussion in nine further media articles. Two items in our database (GR6 \& 7) also made the link with the Brexit referendum result which had just been announced - relevant because Greece was at the time discussing the possibility of leaving the EU. In GR7 the author uses PIAAC to compare Greece with Sweden, Venezuela and the United Kingdom in terms of political maturity. The enmeshing of political issues with the coverage in this way was very notable and a great contrast to the coverage in Singapore.

The very different tone of the coverage in the two countries is especially interesting given that both were, overall, below the OECD average in the league table of 33 nations. The Greek media did not make any positive points for example that educational levels of young Greeks overall is increasing, or that - unusually - women were higher performing than men. Five of the eight headlines were negative and the remaining three were indeterminate (see Appendix 1). There seemed to be a halo of negativity around the results and the political discourse more generally, that did not allow for rays of sunshine or silver linings. The key headline could have been "More bad news for Greece!".

\section{New Zealand and Slovenia}

New Zealand and Slovenia present two further cases of countries with contrasting performances on the PIAAC survey. Both had taken part in early surveys of adult skills. NZ was ranked $4^{\text {th }}$ in the PIAAC league table for literacy and numeracy and first for PSTRE, while Slovenia came in below the OECD average alongside Greece and Singapore. 
New Zealand is an oceanic country of around 4.6 million people the majority of whom are of European descent, $15 \%$ Maori, Pacific Islanders $7 \%$ and $87 \%$ live in cities mainly in the north island. Official languages are English, Maori and Sign Language.

The economy and currency are strong despite some slowdowns following the 2008 recession. The unemployment rate is currently 5\%. There is a strong flow of people both in and out of the country: almost a quarter of the highly skilled population live abroad, mainly in nearby Australia, while highly skilled immigrants enter the country to cover skills shortages (Dumont \& Lemaître, 2005). Australia is a dominant influence on the economy and the media. There are long standing ties with the UK which has affected the structure of political and social institutions. Since 2001, New Zealand has invested heavily in adult literacy and numeracy with a national initiative (NZ Ministry of Education, 2001) that resembles the English Skills for Life strategy also launched in 2001 (DfEE, 2001) and this is cited in the media as paying off in terms of increased literacy scores, though numeracy has remained static.

New Zealand has no truly national paper. The most widely read newspapers are city-based with the Auckland-based NZ Herald having the widest circulation. There are many local and free (community) papers, also a large number of online sites and portals that are increasingly important in the media landscape.

Thirteen news items were identified. Given that the country scored extremely well in the PIAAC survey, our informant described the media coverage as low key (although self-congratulatory) compared with previous adult skills surveys. She suggests that this was perhaps due to the already well-established awareness of the issue of adult skills and the long-standing funded strategy to develop them. However, she notes that the results are unlikely to give rise to new policy initiatives: in NZ. Organisations involved in adult literacy and numeracy teaching have had massive 
funding cuts in the last few years. It is unlikely that the government will be willing to revisit these decisions given the latest results.

Ethnic differences were highlighted in a positive way reflecting government policy and recent reductions in measured inequality between the dominant European heritage population and Maori and Pacific Islanders:

Pacific Peoples Minister Peseta Sam Lotu-liga says new literacy and numeracy results for Pacific adults are great news.... Providing adults with access to education and training such as the Youth Guarantee scheme and the Maori and Pasifika Trades Training programme, help adults into work and delivers better living standards for Pacific people. [NZ6]

All three PIAAC skill dimensions were mentioned in the media and each had a different profile of results: literacy had improved since it was last measured in the IALS survey, numeracy was static while PSTRE was high. PSTRE claimed uneven attention in the media and as our informant pointed out, this had not been part of the government's adult skills strategy so the high performance on this has to be explained in some other way. There was little interest in or information about the methodology of the survey.

Slovenia became an independent country in 1991 and joined the European Union in 2004. It has a population of around 2 million people, half of whom live in rural areas. Although the transition from socialist to a market economy was accomplished without major conflict and the country experienced stable economic growth after joining the EU, it was seriously affected by the 2008 recession and lost jobs. It is slowly recovering and the unemployment rate is currently $8 \%$ with youth unemployment higher at around $13 \%$. Compulsory schooling is 6-15 years. Internet use has increased from $15 \%$ in 2000 to $69 \%$ currently but print newspapers retain wide readership. It has a centre left government in power.

Slovenia inherited a long tradition of adult education and androgogical theoretical approaches to adult learning. The present government has taken on the EU lifelong learning agenda, with a White Paper on Adult Education published in 2011 and 
an action plan on adult learning, but no major funding has yet materialised. It has an active advocate in the National Slovenian Institute for Adult Education (SIAE) which collaborates with the government to carry out PIAAC in Slovenia, and works actively to promote the state strategy on adult learning. The PIAAC Slo team prepared press releases and organised an in-country launch event which formed the basis for several of the media reports. The team subsequently monitored the media coverage so we have, as well as the local informant report, a list compiled by them of the media reports which is much more detailed than anything from the standard database searches since it includes Slovenian language items (http://piaac.acs.si/mediji/piaac/).

On the journalist preparation and training, our informant explains:

Two weeks before the results were released, there was a one hour meeting in Ministerial cabinet with journalists, where the experts exactly explained the methodology and way of showing results. There were almost all key journalists, who then reported about the results on a national level. They summarized the key results from Slovenia report very exactly. There was no methodological misunderstanding in their interpretations.

Eleven news items were identified . Practically all the reports mentioned statements from the Minister of Education. Some mentioned the statements of the OECD representative who was a guest at the press conference. An economics professor and a primary headmaster were also quoted.

The results highlighted by the OECD in its country notes (see Appendix 1) were closely followed with two exceptions. Firstly, the wider links of the results with employment, wages and "non-economic" outcomes hardly featured in the coverage. Only one report (SLO3) discussed these issues and the need to develop a "business culture. On the other hand, while refugee populations were not mentioned by the OECD, dealing with these has been an important recent issue for the country and is linked in the media coverage to low skills among migrant groups 
Our informant commented that the common message was:

"We had bad results, something is wrong"......."the headlines were shouting Slovenians are illiterate" DNEVNIK, the second largest circulation paper, carried this negative headline on the day the findings were released: "One in four inhabitants of Slovenia is semi-literate" [SLO2] and Finance, a business oriented paper, was also negative in its coverage calling the results a "Catastrophe"[SLOl].

Both positive and negative aspects of the findings got some coverage, however, and details were given about the test items, the interview process and issues with terminology. This suggests that the careful preparation activities with journalists may have increased the methodological comment in the media coverage and its accuracy. Positive aspects mentioned were the better scores of younger people and the overall improvement of literacy since IALS. The negatives were mainly presented in terms of problems with the schooling system (SLO10).

\section{Observations and conclusions across the four countries}

Methodologically it was complex to identify the multiple sources of media coverage for these countries. The coverage itself can be repetitive as one source borrows from another or simply reproduces a government press release, perhaps with a variation in the headline. Identifying and translating items in different languages adds to the uncertainty of a comprehensive analysis.

Both the OECD and national media are interested in trends over time, so age variations in scores were a focus of attention across all the 4 countries examined here. At present only NZ and Slovenia have comparative findings from earlier surveys (IALS and ALL) but over time more longitudinal data will be available for all countries, so there will be more data on which to base these interpretations.

In terms of policy outcomes, 3 of the 4 countries are already strongly aligned with the OECD vision for their economy and the importance of lifelong learning with 
Singapore and NZ having well-funded programmes already in place. Greece is the outlier on this but the depressed state of the economy and the outward migration of skilled people overshadows adult education policy action with few resources to develop new initiatives.

Perhaps, as pointed out by the informants in Singapore and NZ, if governments are already addressing lifelong learning and the survey results are seen to be good or improving, it is unlikely the PIAAC will prompt new change initiatives even if there are still issues to be addressed. In cases where the results are poor, the likelihood of reform will depend on the resources available and whether other issues appear to be more pressing, as is the situation in Greece. Slovenia with strong, state advocates for lifelong learning, along with the possibility of accessing EU funding to develop adult skills is perhaps the most likely of the four case study countries to development new policy initiatives and it is the only one of the four whose Minister has made an explicit commitment to this (SLO3).

In summary, media coverage of PIAAC\#2 was uneven and the findings were not always treated as new information - especially where national studies have previously reported the same results or a relevant existing policy is already in place. There are many other pressing issues that claim a place on the front page and preoccupy audiences. Three of the four countries reviewed in this paper have poor results in at least one dimension of the survey, yet the way the media perceive and respond to these findings differs considerably. In only one country (Slovenia) did it seem likely that the results would be used to develop positive change in adult skills policy.

As documented above, the country notes provided by the OECD strongly frame and shape what is reported in the national media and, unlike findings for the UK, France and Japan in the first wave of PIAAC (Yasukawa et al 2016), there was little evidence 
in the PIAAC\#2 countries studied here of national issues reshaping the OECD analysis. However, the media coverage did depart from the OECD country notes in two significant ways.

Firstly, as can be seen in the country notes in Appendix 2, immigrant populations are only mentioned by the OECD in relation to NZ, but in fact, immigration patterns and attitudes are significant in all four countries. They play out very differently in each and this is reflected in the media coverage and comments from informants. Refugee populations prompt new anxieties and skills challenges in Slovenia and Greece, while the significant outward migration of highly skilled people in Greece and the two-way exchange of inward and outward skilled migrants in NZ is commented onas problematic (NZ13).

On the other hand, the media discourse does not pick up strongly on the OECD's preoccupation in every one of the country notes with the employment and wider 'noneconomic' outcomes of skills development. Rather, they still look to the initial education system to identify problems and solutions.

The three skills dimensions are discussed separately in thePIAAC\#2 coverage, especially the implications of PSTRE as a new domain and its relation to computer use (e.g. NZ 4 and SLO11). As non-cognitive personality measures become embedded in future OECD discourse and test construction (see OECD, 2017:16) there will be even more need to understand the variations and interactions of the different dimensions with national discourse and policy.

Methodology was barely mentioned, except for Slovenia where government briefings and journalist training seems to have had an effect. There was little critical attention to the findings themselves. The quantified facts generated by the survey and selected by the OECD were accepted without question. The high levels of migration 
experienced by these four countries should call into question one of the basic assumptions of the survey - that the nation state is an appropriate unit of analysis for assessing adult skills. Even the manifest limitation of an English language test being used with a predominantly Chinese-speaking older population in Singapore did not prompt criticism of the OECDs choice. Thus, there was no evidence in our data of any 'post-truth' dismissal of expert knowledge and such a lack of scrutiny poses a challenge to goals of inclusiveness and relevance claimed for the test.

Although within population variations are discussed in the body of news items, headlines often simply highlight the overall national ranking compared with other countries. As has been found in other studies, the development of international comparative testing tends to direct attention away from systemic issues like inequality and towards external reference countries (Waldow et al 2014). A range of external referent countries are used and these give clues as to how the countries identify themselves: Singapore, as a cosmopolitan trading centre, refers to an eclectic range of countries; NZ refers mostly English-speaking developed countries rather than to Pacific Asia; Greece to nearby countries in the EU; Slovenia compares itself with other former communist countries in Eastern Europe as well as in the EU more generally. And everyone refers to the top scorers: Japan, Finland, and Sweden (Takayama, et al, 2013).

The predominance of the school-based PISA survey as a subject for media, policy and research attention sets high expectations that other ILSAs will cause equal excitement and perturbation in national contexts. But PISA may be an exception. The present study suggests that survey findings about adult skills struggle to attract serious attention and debate in the media (see also Cort and Larson, 2015). Even when the findings are reported, the implications for adult and lifelong learning policy are not reliably drawn. 
PIAAC is a young assessment initiative and it is important to follow the afterlife of the findings, especially as new waves of the survey are carried out and reported, and more countries participate in it. Media discourse and awareness may develop over the longer term along with policy response as Pons (2011) describes for PISA. This initial analysis of media coverage in four countries, however, suggests there is no straightforward route between the PIAAC test findings and their incorporation in to national contexts, and no predictable likelihood of positive policy change in relation to adult lifelong learning.

\section{References}

Addey, C., S. Sellar, G. Steiner-Khamsi, B. Lingard, \& A. Verger (2017). The Rise of International Large-Scale Assessments and Rationales for Participation. Compare 47 (3): 434-452.

Addey, C \& Sellar S. (2017). Why do countries participate in PISA? Understanding the role of international large-scale assessments in global education policy. In Verger, A. Novelli, M. Altinyelken, H.K. (2nd edition) Global Education Policy and International Development: New Agendas, Issues and Policies. Bloomsbury Academic Carvalho, L. M. (2012). The fabrications and travels of a knowledge-policy instrument. European Educational Research Journal, 11(2), 172-188.

Coben, D., Miller-Reilly, B., Satherley, P. \& Earle, D. (2016). Making the most of PIAAC: Preliminary investigation of adults' numeracy practices through secondary analysis of the PIAAC dataset. Adults Learning Mathematics: An International Journal, 11(2), $27-40$ 
Cort, P. \& Larson, A. (2015). The non-shock of PIAAC-Tracing the discursive effects of PIAAC in Denmark. European Educational Research Journal, 14(6), 531-548.

DfEE, 2001 Skills for Life: The National Strategy for Improving Adult Literacy and Numeracy. Department for Education and Employment.

Fenwick, T., R. Edwards, \& P. Sawchuk, eds. (92011). Emerging Approaches to Educational Research: Tracing the Sociomaterial. Abingdon: Routledge.

Fischman, G. E., Topper, A. M., Silova, I., Goebel, J., \& Holloway, J. L. (2018) Examining the influence of international large-scale assessments on national education policies, Journal of Education Policy, DOI: 10.1080/02680939.2018.1460493 Guadalupe, C. (2015). How Feasible is it to Develop a Culturally-Sensitive Large-Scale, Standardised Assessment of Literacy Skills?.in Hamilton,M. Maddox, B \& Addey, C. Eds Literacy as numbers: Researching the politics and practices of international literacy assessment, 111-128.

Grek, S. (2010). International organisations and the shared construction of policy 'problems': Problematisation and change in education governance in Europe. European Educational Research Journal, 9(3), 396-406.

Gorur, R. (2011). ANT on the PISA trail: Following the statistical pursuit of certainty. Educational Philosophy and Theory, 43 (s1), 76-93

Hamilton, M. (2017). How International Large-Scale Skills Assessments engage with national actors: mobilising networks through policy, media and public knowledge. Critical Studies in Education, 1-15.

Hamilton, M. (forthcoming). The Discourses of PIAAC: Re-imagining Literacy through Numbers. In Finnegan, F. and Grummell, B. (Eds) Power and Possibility: Adult education in a diverse and complex world. Sense Books. 
Hanushek, E. \& L. Woessmann (2015). Universal Basic Skills: What Countries Stand to Gain. OECD Publishing, 2015

Henry, M., Lingard, R., Rizvi, F., \& Taylor, S. (2001). The OECD, globalisation and education policy. Elsevier Science.

Hopfenbeck, T. N. \& Görgen, K. (2017). The Politics of PISA: The media, policy and public responses in Norway and England. European Journal of Education 52 (2): 192205.

Javrh, P. (2016) How to work with media and policy makers. Presentation at ESRC Seminar on The Politics of Reception, Lancaster, April.

https://youtu.be/6CWj8AF6Eeg (Accessed 7/5/2017)

Kelly, D. M. (2011). The public policy pedagogy of corporate and alternative news media. Studies in Philosophy and Education, 30(2), 185-198.

Kirsch, I., \& Lennon, M. L. (2017). PIAAC: a new design for a new era. Large-scale Assessments in Education, 5(1), 11. DOI 10.1186/s40536-017-0046-6

Knight, M. (2015) Data journalism in the UK: a preliminary analysis of form and content. Journal of Media Practice 16 (1): 55-72

Latour, B. (2005) Reassembling the social: An introduction to actor-network-theory. Oxford university press.

Luke, A., Freebody, P., Lau S. \& Saravanan G. (2005) Towards research-based innovation and reform: Singapore schooling in transition. Asia Pacific Journal of Education 25:1, 5-28.

Milana, M., Holford, J., Jarvis, P., Waller, R., \& Webb, S. (2014). Skills assessment, PIAAC and the adult literacy agenda. International Journal of Lifelong Education, $33(2), 121-124$. 
New Zealand Ministry of Education (2001) More than words: The New Zealand adult literacy strategy. Ministry of Education.

Pawson, R. (2006). Evidence-based policy: a realist perspective. Sage.

Pons, X. (2011). What Do We Really Learn from PISA? The Sociology of its Reception in Three European Countries (2001-2008) 1. European Journal of Education, 46(4), $540-548$

OECD (2013) The Survey of Adult Skills (PIAAC): Implications for education and training policies in Europe https://www.oecd.org/site/piaac/PIAAC\%20EU\%20Analysis\%2008\%2010\%202013\%2 0-\%20WEB\%20version.pdf OECD (2017), OECD Skills Outlook 2017: Skills and Global Value Chains, OECD Publishing, Paris. DOI: http://dx.doi.org/10.1787/9789264273351-en O'Keeffe, C. (2015) Assembling the adult learner: global and local e-assessment practices' $\mathrm{PhD}$ Thesis, Lancaster University.

Ozga, J., Dahler-Larsen, P., Segerholm, C., \& Simola, H. (Eds.). (2011). Fabricating quality in education: Data and governance in Europe. Routledge.

Rawolle, S., \& Lingard, B. (2014). Mediatisation and education: A sociological account. Mediatisation of communication, 595-614.

Roseveare, D. (2014) PIAAC and the OECD Skills Strategy. INSIGHT Seminar 4 Academy of the social sciences https://www.acss.org.uk/iag-seminar-series-seminar-4report/ https://campaignforsocialscience.org.uk/wpcontent/uploads/2013/07/Professional-Briefing-international-insights.pdf (p.3) Schleicher, A. (2016) Why Skills Matter http://oecdeducationtoday.blogspot.co.uk/2016/06/why-skills-matter.html (Accessed $8 / 5 / 2017)$ 
Sellar, S. \& Lingard, B. (2015). New Literacisation, Curricular Isomorphism and the OECD's PISA. In Hamilton, M. Maddox, B. \& Addey, C. (eds) Literacy as Numbers: Researching the Politics and Practices of International Literacy Assessment, Cambridge. 17-34.

Stack, M. (2016). Global university rankings and the mediatization of higher education. Springer.

Steiner-Khamsi, G. (2003). The politics of league tables. JSSE-Journal of Social Science Education, 2(1).

Takayama, K., Waldow, F., \& Sung, Y. K. (2013). Finland has it all? Examining the media accentuation of 'Finnish education' in Australia, Germany and South Korea. Research in Comparative and International Education, 8(3), 307-325.

Tan, C. (2017). Lifelong learning through the SkillsFuture movement in Singapore: challenges and prospects. International Journal of Lifelong Education, 36(3), 278-291. Yasukawa, K., Hamilton, M., \& Evans, J. (2017). A comparative analysis of national media responses to the OECD Survey of Adult Skills: policy making from the global to the local? Compare: A Journal of Comparative and International Education, 47(2), 271-285.

Waldow, F., Takayama, K., \& Sung, Y. K. (2014). Rethinking the pattern of external policy referencing: media discourses over the 'Asian Tigers''PISA success in Australia, Germany and South Korea. Education, 50(3), 302-321.

Walker, J., \& Rubenson, K. (2014). The media construction of an adult literacy agenda in Canada. Globalisation, Societies and Education, 12(1), 143-163. 
APPENDIX 1: Details of Media Coverage of PIAAC\#2 in Four Countries during the week after the release of findings on June $28^{\text {th }} 2016$

\section{Singapore SING 1-16}

1. Singapore adults lagging behind in literacy, maths: OECD (Today, 28/6/2016)

2. Young Singaporeans top competency rankings while older citizens lag behind, study finds (Straits Times, 28/6/2016)

3. Singapore adults 'below average' in literacy; above average in problem-solving: $\mathrm{OECD}$ survey (Channel Newsasia, 28/6/2016)

4. Study finds Singapore adults lag in literacy compared with OECD average (The Malay Mail, online newspaper, 28/6/2016)

5. Older Singaporeans are terrible at English and maths, reveals OECD survey (Singapore Business Review, 29/6/2016)

6. Skills gap between younger and older Singapore workers: OECD study (Straits Times, 29/6/2016)

7. Finding solutions to upgrade, reward worker skills in Singapore (Today, online news 29/6/2016)

8. Higher skills likely to bring more pay in S'pore than in other countries: Survey (Today, 29/6/2016)

9. Critical skills gap found for Singapore staff (HRD Singapore Blog - Milos Bolza 29/6/2016)

10. 5 things about that OECD study you didn't read in the news (Andrea Wang, Blog, The Middleground, independent news site 29/6/2016)

11. Study three more years, earn 30\% more: OECD survey (The Middleground, independent news site, 29/6/2016)

12. The International adult Skills Assessment shows that national language proficiency is less than the average (29/6/2016 Chinese language source not identified)

13. Singaporean's language and computational ability is below international level (New Tomorrow Chinese language 29/6/2016)

14. Overall language level is below the OECD but young people are among the top (My Paper, free, bilingual (English/Chinese)newspaper, 29/6/2016)

15. The OECD International Adult Skills Assessment shows that the national language and computational skills are below average (Lianhe Zaobao, largest circulation Chinese Language newspaper in Singapore, 29/6/2016)

16. Skills push on the right track (Straits Times, 2/7/2016)

\section{New Zealand NZ 1-13}

1. New-Zealand's adult-literacy-among-the-best_(Stuff,_online news site 28/6/2016)

2. New study finds when Kiwis are at their smartest (NZ Herald, 28/6/2016)

3. New Zealand fourth in OECD for adult literacy (Yahoo NZ top news stories, 28/6/2016)

4. NZ Best in World at computer-based problem solving (28/6/2016 Radio NZ)

5. Minister Welcomes adult literacy, numeracy results (28/6/2016 Radio NZ)

6. Pacific literacy and numeracy skills improve (Scoop, online news site 29/6/2016)

7. New Zealand fourth in OECD for adult literacy, (Beehive, 29/6/2016 Government press release, carried in 3 other outlets)

8. How Plain English Can Help when education hasn't. (Scoop 29/6/2016) 
9. Kiwis' problem-solving smarts rank high (NZ Radio National News 29/6/2016). This article also repeated in the New Zealand Herald (hard copy) headlined: NZ gains in literacy rankings Wed 29/06/2016 on the bottom of p.A7

10. NZ: NZ now fourth in OECD for Adult Literacy (Iranian Students News Agency, online 30/6/2016)

11. NZ A Leader in Tech Based Problem-Solving (TransTasman, online weekly news site, 30/6/2016)

12. NZ Adult Literacy Skills among OECDs best (30/6/2016, The Press, daily broadsheet, Christcurch)

13. Skills matter.... And we already seem to have them (30/6/2016 Blog from sciblog.co.nz by Michael Reddell, economist)

\section{Slovenia SLO 1-11}

1. Catastrophe - every fourth inhabitant of Slovenia almost functionally illiterate. (Finance newspaper 28/6/2016)

2. Every fourth inhabitant of Slovenia barely literate. (Dnevnik diary, 28/6/2016)

3. Adult Slovenians are under-literate. (Delo, Working 28/6/2016)

4. Low adult literacy among Slovenians Results of the PIAAC survey in Slovenia commented on by guest Dr. Dušana Findeisen (Echoes of RTV Slovenia 28/6/2016)

5. Discussion of the results of the research skills of adults PIAAC in Slovenia. (Log on RTV Slovenia, 28/6/2016)

6. Dr.Petra Javrh spoke about the results of the PIAAC research on the skills of adults in Slovenia and showed how respondents solved tasks on the computer. (Kanal A,. Commercial TV 28/6/2016)

7. OECD: Slovenians are below average in literacy (Portal Žurnal24.si, online news site 28/6/2016)

8. Adult Slovenes are below average in terms of literacy, computing and problem solving (Evening, general interest web-portal, 28/6/2016)

9. Slovenians are below average in literacy, computing and problem solving (24ur, news portal, also repeated on Kanal A 28/6/2016)

10. Literacy: how full is the glass? (Dnevnik diary, newspaper 30/6/2016)

11. The Marathon and the roundabout: almost one in five adults do not use the computer. (Delo, Working, newspaper 30/6/2016)

\section{Greece GR 1-8}

1. The skills of Greeks are low - according to the latest research of the OECD. (Kathimerini 29/6/2016, Front page)

2. Greeks are lacking in skills (Kathimerini $29 / 6 / 2016$, p.6) Link to this article also on Nea Symera, general online news site)

3. Superficial knowledge in Greece (Imerisia, daily financial newspaper 29/6/2016)

4. Results of the Assessment of Adult Abilities. (Dictyo.gr online network 29/6/2016). This article is probably a press release as it has also been found in 3 other websites

5. The new OECD survey gives a slap to the Greek education system (iapopsi.gr online politics and sports weekly, 29/6/2016) Same article also found in tribune.gr

6. So What? (Kathimerini 30/6/2016, Page 2) Comment piece on Brexit and PIAAC, divided in two)

7. Good and bad referenda (Kathimerini, 1/7/ 2016) Comment piece on Brexit, referenda, which then ends with discussing PIAAC)

8. Exit from a country without skills (Kathimerini 3/7/2016) Comment piece 


\section{APPENDIX 2: KEY ISSUES IN OECD COUNTRY NOTES FOR FOUR CASE STUDY COUNTRIES}

\section{Compared with other countries participating in PIAAC.}

\begin{tabular}{|c|c|c|c|}
\hline Singapore & Greece & $\mathrm{NZ}$ & Slovenia \\
\hline $\begin{array}{l}\text { - Adults showed below-average } \\
\text { proficiency in literacy and } \\
\text { numeracy, but above-average } \\
\text { proficiency in problem solving } \\
\text { technology-rich environments. }\end{array}$ & $\begin{array}{l}\text {-There are fewer high scorers } \\
\text { and more low scorers in } \\
\text { literacy and numeracy. }\end{array}$ & $\begin{array}{l}\text { - Adults score above the } \\
\text { OECD average in literacy, } \\
\text { numeracy and problem } \\
\text { solving in technology-rich } \\
\text { environments. }\end{array}$ & $\begin{array}{l}\text { - Adults score below } \\
\text { the OECD average in } \\
\text { literacy, numeracy and } \\
\text { problem solving in } \\
\text { technology-rich } \\
\text { environments. }\end{array}$ \\
\hline $\begin{array}{l}\text { A wide contrast exists between } \\
\text { older and younger adults with } \\
\text { the youngest age group scoring } \\
\text { the highest of all PIAAC\#2 } \\
\text { countries }\end{array}$ & $\begin{array}{l}\text { - In contrast to what is } \\
\text { observed in other countries, } \\
25-34 \text {-year-olds perform as } \\
\text { well in literacy as } 55-65 \text {-year- } \\
\text { olds. }\end{array}$ & $\begin{array}{l}\text { - The immigrant population } \\
\text { is one of the most skilled } \\
\text { across OECD countries. At } \\
\text { the same time, native-born } \\
\text { speakers of English as a } \\
\text { second language are over- } \\
\text { represented among adults } \\
\text { with low proficiency. }\end{array}$ & $\begin{array}{l}\text { - Around one in four } \\
\text { adults has poor literacy, } \\
\text { numeracy and } \\
\text { problem-solving skills, a } \\
\text { slightly larger } \\
\text { proportion than the } \\
\text { OECD average. }\end{array}$ \\
\hline $\begin{array}{l}\text { - The disadvantage of older } \\
\text { adults is partly explained by the } \\
\text { higher prevalence of non-native } \\
\text { English speakers and by their } \\
\text { relatively low levels of } \\
\text { educational attainment. }\end{array}$ & $\begin{array}{l}\text { - Is one of the few countries } \\
\text { where women outperform } \\
\text { men in literacy. }\end{array}$ & $\begin{array}{l}\text { - The link between skills and } \\
\text { age, gender, education and } \\
\text { social background is weaker } \\
\text { than in other countries. } \\
\text { However, sharp ethnic } \\
\text { differences exist, particularly } \\
\text { for Māori and Pacific } \\
\text { peoples. }\end{array}$ & $\begin{array}{l}\text { - Adults' literacy scores } \\
\text { have improved } \\
\text { substantially over the } \\
\text { past two decades. }\end{array}$ \\
\hline $\begin{array}{l}\text { - The dispersion of proficiency } \\
\text { scores is wider than in most } \\
\text { other participating } \\
\text { countries/economies. }\end{array}$ & $\begin{array}{l}\text { - Tertiary-educated adults in } \\
\text { Greece have relatively low } \\
\text { proficiency in literacy, } \\
\text { numeracy and problem solving } \\
\text { in technology-rich } \\
\text { environments. }\end{array}$ & $\begin{array}{l}\text { - Literacy and numeracy } \\
\text { skills have an above average } \\
\text { positive impact on labour } \\
\text { force participation and } \\
\text { wages. }\end{array}$ & $\begin{array}{l}\text { - The variation in } \\
\text { Slovenian adults' } \\
\text { proficiency scores is } \\
\text { greater than on } \\
\text { average across OECD } \\
\text { countries. }\end{array}$ \\
\hline \multirow[t]{3}{*}{$\begin{array}{l}\text { - There is a strong link with } \\
\text { wages and non-economic }{ }^{1} \\
\text { outcomes of skills proficiency } \\
\text { and frequent use of skills at } \\
\text { work }\end{array}$} & $\begin{array}{l}\text { - The relationship between } \\
\text { skills proficiency and non- } \\
\text { economic outcomes is } \\
\text { considerably weaker than in } \\
\text { other participating } \\
\text { countries/economies. }\end{array}$ & $\begin{array}{l}\text { - The link between literacy } \\
\text { and non-economic } \\
\text { outcomes is in line with } \\
\text { other OECD countries. }\end{array}$ & $\begin{array}{l}\text { - Skills differences are } \\
\text { linked to age, education } \\
\text { and social background. }\end{array}$ \\
\hline & $\begin{array}{l}\text { - Workers in Greece use their } \\
\text { numeracy and problem- } \\
\text { Average use of skills at work } \\
\text { but a weak link of skills } \\
\text { proficiency with wages }\end{array}$ & & $\begin{array}{l}\text { - Most workers in } \\
\text { Slovenia are well- } \\
\text { matched with their jobs }\end{array}$ \\
\hline & & & $\begin{array}{l}\text { - Proficiency in literacy } \\
\text { and numeracy has a } \\
\text { positive impact on } \\
\text { labour force } \\
\text { participation and } \\
\text { wages, and on several } \\
\text { non-economic } \\
\text { outcomes }\end{array}$ \\
\hline
\end{tabular}

${ }^{1}$ Non-economic outcomes are identified as trust in others, political efficacy, participation in volunteer activities and self-reported health. 
i The following countries participate in PIAAC:

Round 1 (2008-2013): Australia, Austria, Belgium (Flanders), Canada, Czech Republic, Denmark, Estonia, Finland, France, Germany, Ireland, Italy, Japan, Korea, Netherlands, Norway, Poland, Russian Federation, Slovak Republic, Spain, Sweden, United Kingdom (England and Northern Ireland), United States

Round 2 (2012-2016): Chile, Greece, Indonesia, Israel, Lithuania, New Zealand, Singapore, Slovenia, Turkey

Round 3 (2016-2019): Ecuador, Hungary, Kazakhstan, Mexico, Peru, United States

ii Sincere thanks are due to all the people who contributed to the research reported in this paper:

Margarita Calderon (Chile)

Cormac O'Keefe (France)

Natalie Papanastasiou, Sofia Ntalapera, Despina Potari, Jeff Evans, Anna Tsatsaroni (Greece)

Ari Danu, Didi Sukyadi David Mallows (Indonesia)

Oren Pizmony-Levy (Israel)

Tomoya Iwatsuki (Japan)

Justina Naujokaitiene (Lithuania)

Janet Coup/Pat Strauss NZ)

Stanley Koh (Singapore)

Petra Javrh (Slovenia)

Caroline Runesdottir (Sweden)

Ahmed Yildez (Turkey)

Keiko Yasukawa (Factiva searches) 